\title{
C-C Chemokine Receptor Type 4
}

National Cancer Institute

\section{Source}

National Cancer Institute. C-C Chemokine Receptor Type 4. NCI Thesaurus. Code C129067.

C-C chemokine receptor type 4 ( $360 \mathrm{aa}, \sim 41 \mathrm{kDa}$ ) is encoded by the human CCR4 gene. This protein is involved in leukocyte chemotaxis. 